\title{
Effects of maternal nuclear genome on the timing of puberty in mice offspring
}

\author{
Yuxun Zhou' ${ }^{1}$, Wangsheng Zhu' ${ }^{1}$, Zhengxia Guo ${ }^{2}$, Ying Zhao ${ }^{2}$, Zijun Song ${ }^{2}$ and Junhua Xiao ${ }^{1,2}$ \\ ${ }^{1}$ Institute of Bioscience and Biotechnology, Donghua University, Shanghai 201620, People's Republic of China \\ ${ }^{2}$ State Key Laboratory of Bioreactor Engineering, East China University of Science and Technology, Shanghai 200237, People's Republic of China \\ (Requests for offprints should be addressed to J Xiao; Email: xiaojunhua@dhu.edu.cn)
}

\begin{abstract}
The timing of puberty is a complex trait which is regulated by environmental and genetic factors, but the detailed regulatory mechanism remains elusive. Maternal nutrition administration during late gestation in rats revealed that the time of onset of puberty in daughter rats was influenced by the mother's nutritional and physiological status during the embryonic development period. In this study, the potential effects of the maternal nuclear genome on the timing of puberty of offspring were investigated. Two inbred strains of mice $(\mathrm{C} 3 \mathrm{H} / \mathrm{HeJ}(\mathrm{C} 3 \mathrm{H})$ and $\mathrm{C} 57 \mathrm{BL} / 6 \mathrm{~J}(\mathrm{~B} 6))$ were used to set up two pedigrees (direct and reciprocal crosses), and the timing of puberty in all these mice (parent, F1 and F2) was recorded (the females were assessed by vaginal opening (VO) and the males by balano preputial separation (BPS)). The results from data of 822 mice showed that: 1) in female mice, the heritability of the timing of puberty in direct and
\end{abstract}

reciprocal crosses is $68.51 \%$ and $63.97 \%$ respectively; 2) in female mice, a significant difference in the timing of puberty is observed between $\mathrm{B} 6$ and $\mathrm{C} 3 \mathrm{H}\left(P=3 \cdot 7 \times 10^{-13}\right)$ mice as well as between direct and reciprocal $\mathrm{F} 1$ hybrids $(P=$ $\left.5 \cdot 4 \times 10^{-3}\right)$, but not between direct and reciprocal $\mathrm{F} 2$ hybrids $(P=0.0941) ; 3)$ in male mice, direct and reciprocal F1 hybrids differ significantly from each other in the timing of BPS $\left(P=2.7 \times 10^{-7}\right)$, while such differences vanish in their male progenitor and progeny. The significant discrepancy between direct and reciprocal crosses in F1 but not in either cross of $\mathrm{F} 2$ hybrids reveals that the maternal nuclear genome has effects on the timing of puberty in mice progeny, probably through imprinting genes or the genes associated with intra-uterine physiological status.

Journal of Endocrinology (2007) 193, 405-412

\section{Introduction}

Puberty is an important developmental stage and has a pervasive relationship with many other aspects of physiology and pathology (Meyer et al. 1991, Loesch et al. 1995, Rockhill et al. 1998, Magnusson et al. 1999, Wattigney et al. 1999, Wyatt et al. 1999). The onset of puberty is one of the key characteristics of this event (Palmert \& Boepple 2001, Palmert \& Hischhorn 2003, Sisk \& Foster 2004, Francis 2005). The calculated heritability in previous studies suggested that up to 50 to $80 \%$ of the variance in the timing of pubertal onset may be genetically controlled (Meyer et al. 1991, Loesch et al. 1995, Palmert \& Boepple 2001, Ibanez et al. 2006). Genetic analysis indicated that familial central precocious puberty was an autosomal dominant transmission with an incomplete, sexdependent penetrance (Vries et al. 2004). Clinical investigation also provided evidence that the $\mathrm{X}$-chromosome was involved in precocious puberty (Jarvela et al. 1993, Grosso et al. 1999, Talaban et al. 2005). GPR54, KISS-1 and CYP3A4 have been nominated as puberty genes by some researchers, as variations in them may cause pubertal abnormality (Kadlubar et al. 2001, 2003, Roux et al. 2003,

Seminara et al. 2003). Quantitative trait loci (QTL) on chromosome 6 and 13 have been shown to regulate the timing of vaginal opening (VO) in mice chromosome substitution strains (CSSs) generated by A/J and C57BL/6J mice (Krewson et al. 2003). However, our understanding of the detailed regulatory mechanism of the timing of puberty is still far from complete (Sisk \& Foster 2004).

On the other hand, more and more evidence has indicated that maternal effects on the timing of puberty onset in offspring cannot be ignored (Cooper et al. 1996, Lumey \& Stein 1997, Magnusson et al. 1999, Adair 2001). A maternal diet low in protein administered during pregnancy and lactation delayed the onset of $\mathrm{VO}$, while a maternal diet high in $\mathrm{n}-6$ polyunsaturated fats administered during pregnancy induced precocious puberty in female rat offspring (HilakiviClarke et al. 1997). The correlation between the age of puberty onset of the mother and the age at which her son or daughter attained pubertal milestones demonstrated that the timing of puberty onset was genetically regulated, especially by the maternal genome (Garn \& Bailey 1978, Persson et al. 1999). In effect, single nucleotide polymorphism (SNP) rs2297660 in the maternal LRP8 gene was found to be 
associated with fetal growth (Wang et al. 2006). All these pieces of evidence indicate that, as well as their own genome, the maternal nuclear genome also has a part to play in the regulation of puberty onset in the progeny.

In order to investigate the potential effects of the maternal genomic background on the timing of puberty in the progeny, two inbred strains of mice $(\mathrm{C} 3 \mathrm{H} / \mathrm{HeJ}$ and $\mathrm{C} 57 \mathrm{BL} / 6 \mathrm{~J}$ ) were used to produce two pedigrees (direct and reciprocal crosses) because the female individuals differ significantly from each other in the timing of $\mathrm{VO}(P<0 \cdot 05$; Nelson et al. 1990). Data on the time of puberty onset in three generations of both genders were recorded and analyzed (the females were assessed by $\mathrm{VO}$ and the males by balano preputial separation (BPS)). From the data of 822 mice in total, significant discrepancies were shown between the direct and reciprocal crosses in F1 but not in F2 hybrids of both genders, which revealed that the maternal nuclear genome had effects on the timing of puberty in the progeny. This was supported by the results of fostering experiments. Heterosis was evaluated in two ways: fecundity in female mice (litter size) and puberty advance in male mice.

\section{Materials and Methods}

\section{Animals and housing}

All mice used in the study were first generation offspring bred in our colony. Parent C57BL/6J (B6) and C3H/HeJ (C3H) mice were obtained from Shanghai SLAC Laboratory Animal Co. Ltd. (Shanghai, P.R.China). The two inbred strains (B6 and $\mathrm{C} 3 \mathrm{H}$ ), direct crosses of $\mathrm{F} 1$ (B6 female $\times \mathrm{C} 3 \mathrm{H}$ male (B6C3H F1)) and F2 (B6C3H F2) hybrids, and reciprocal crosses of $\mathrm{F} 1$ (C3H female $\times \mathrm{B} 6$ male $(\mathrm{C} 3 \mathrm{HB} 6 \mathrm{~F} 1))$ and $\mathrm{F} 2$ (C3HB6 F2) hybrids were studied.

All mice used in this study were housed in standard polysulfone microisolator cages with hardwood chips (SLAC Laboratory) and were allowed unlimited access to water and food (SLAC Laboratory). During mating, pregnancy and lactation, mice were fed a breeder diet.

Animals were maintained on a $12 \mathrm{~h}$ light: $12 \mathrm{~h}$ darkness schedule (lights on at $0600 \mathrm{~h}$ ) at a mean ambient temperature of $23-25^{\circ} \mathrm{C}$. For breeding, individual males were placed in a cage with 2-3 females until each female was obviously pregnant. To minimize the exposure of female pups to male pheromonal and hormonal signals, each female breeder was then isolated in a clean cage containing a sterile cotton nestlet for the remainder of the pregnancy, and the date of birth was designated as the day pups were observed. Pups were weighed daily and weaned between the ages of 20 and 21 days, and males and females were then housed separately. No more than 5 female pups were housed per cage to ensure that access to food and water was unfettered.

Animals in this study were housed one genotype per shelf; cages containing males were interspersed between cages containing females to equalize pheromonal exposures, and genotypes were rotated weekly on the shelves to avoid placement bias. All animal procedures were conducted in accordance with the Experimental Animal Management Ordinance of the People's Republic of China (1988).

\section{Fostering experiment}

Twenty $\mathrm{C} 3 \mathrm{H}$ and $\mathrm{B} 6$ female mice (10 of each inbred strain) were mated with males of the alternative strain. $\mathrm{C} 3 \mathrm{H} \times \mathrm{B} 6 \mathrm{~F} 1$ and $\mathrm{B} 6 \times \mathrm{C} 3 \mathrm{H}$ F1 progeny were separated from their mothers on the day after their birth and fed randomly by lactating B6 female mice until weaning. Thus hybrid progeny of both crosses were fostered by maternal parents with the B6 genetic background. Litter size was curtailed to 6-8 pups. Another group of female mice mated with homologous males were manipulated in the same way for comparison. Pups were weighed daily until all the mice of the same cross and gender attained pubertal onset.

\section{Assessment of pubertal onset}

Beginning on the day of weaning, mice were examined daily between 0800 and $1100 \mathrm{~h}$ and the dates of $\mathrm{VO}$ for females and BPS for males were recorded together with the concurrent body weights of the animals.

\section{Statistical analysis}

Data were recorded as the mean, the standard deviation and the variation. Mean two-tailed, nonparametric tests for independent variables (Mann-Whitney $U$ tests) were used for comparisons of time of puberty onset because of the nonnormal distribution of the timing of puberty in mice. Differences with $P \leq 0.05$ were considered statistically significant.

Heritability was calculated as

$h^{2}=\frac{\left[V_{\mathrm{F} 2}-1 / 3\left(V_{\mathrm{P} 1}+V_{\mathrm{P} 2}+V_{\mathrm{F} 1}\right)\right]}{V_{\mathrm{F} 2}}$

$V_{\mathrm{F} 2}, V_{\mathrm{P} 1}, V_{\mathrm{P} 2}$ and $V_{\mathrm{F} 1}$ are the computed variances (equal to the square of the standard deviation) for the F2, parental (P) 1, $\mathrm{P} 2$ and $\mathrm{F} 1$ populations respectively. Analyses were performed using SPSS software (Chicago, IL, USA).

\section{Results}

Distribution of timing of puberty in different generations of direct and reciprocal pedigrees

The timing of puberty onset in female and male mice is described in Figs 1 and 2. Only the data from litters of normal size were analyzed because litter size may influence the trait (evaluated by distribution of litter size in each generation). In our study, data from 414 out of 564 female mice and 408 out of 549 male mice were used. 


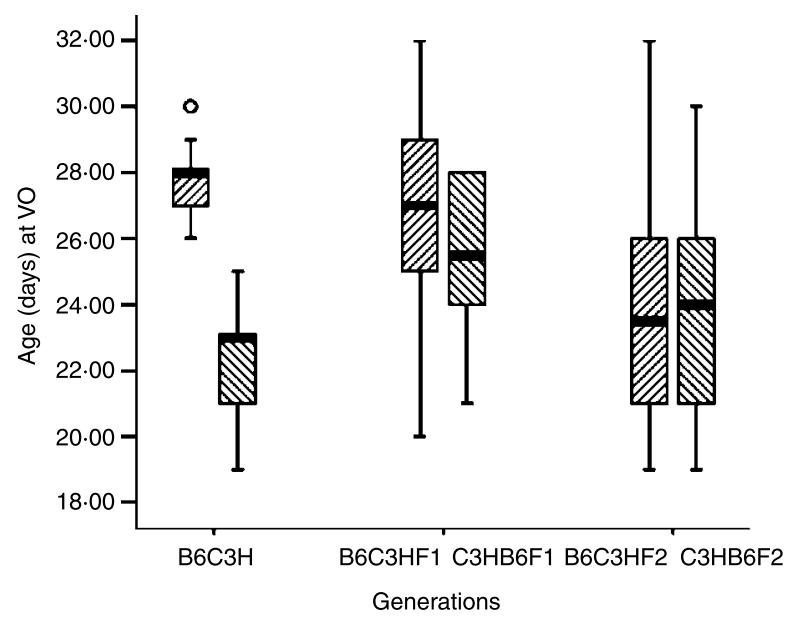

Figure 1 Comparison of age at VO between maternal strains, direct and reciprocal crosses in F1 and F2 hybrids of female mice. Box plots indicate the median (dark bar), 25th and 75th percentiles (borders of boxes) and $12 \cdot 5$ th and $87 \cdot 5$ th percentiles (whiskers). Open circle represents the outlying value. Significant difference in timing of $\mathrm{VO}$ existed between $\mathrm{B} 6$ and $\mathrm{C} 3 \mathrm{H}$ maternal strains $(P<$ $\left.10^{-12}\right)$, and B6C3H F1 and C3HB6 F1 hybrids $(P<0 \cdot 01)$, but not between $\mathrm{B} 6 \mathrm{C} 3 \mathrm{H}$ F2 and C3HB6 F2 hybrids $(P>0 \cdot 5)$.

The comparison of the timing of puberty between direct and reciprocal crosses

In female mice, $\mathrm{VO}$ occurred significantly earlier in $\mathrm{C} 3 \mathrm{H}$ compared with $\mathrm{B} 6$ mice $\left(P=3 \cdot 7 \times 10^{-13}\right)$ and such statistical discrepancy also existed between C3HB6 F1 and B6C3H F1 $\left(P=5.4 \times 10^{-3}\right)$ hybrids, but the difference vanished between B6C3H F2 and C3HB6 F2 hybrids $(P=0.941$; Fig. 1). In male mice, a significant difference in the timing of BPS was only observed between the direct and reciprocal crosses in $\mathrm{F} 1$ hybrids $\left(P=2 \cdot 7 \times 10^{-7}\right)$, and not in paternal strains $(P=0 \cdot 149)$ or in $\mathrm{F} 2$ hybrids $(P=0 \cdot 216$; Fig. 2$)$.

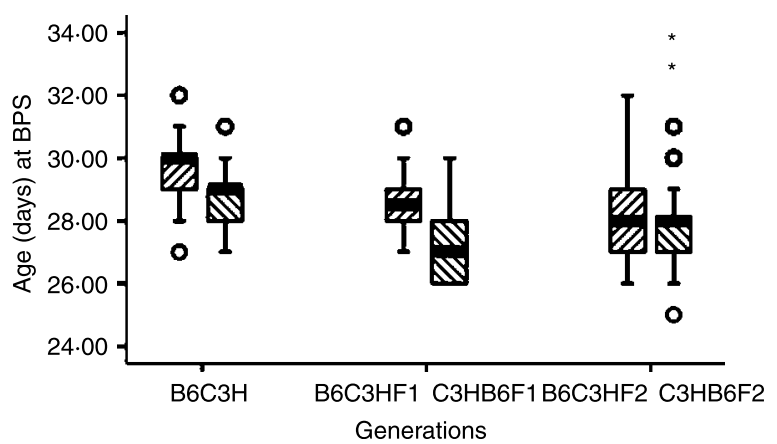

Figure 2 Comparison of age of BPS between paternal strains, direct and reciprocal crosses in F1 and F2 hybrids of male mice. Box plots indicate the median (dark bar), 25th and 75 th percentiles (borders of boxes) and $12 \cdot 5$ th and $87 \cdot 5$ th percentiles (whiskers). Open circles and stars represent the outlying values and extreme outlying values respectively. Significant difference in timing of BPS existed between B6C3H F1 and C3HB6 F1 hybrids $\left(P<10^{-6}\right)$, but not between B6 and $\mathrm{C} 3 \mathrm{H}$ paternal strains $(P>0 \cdot 1)$ or $\mathrm{B} 6 \mathrm{C} 3 \mathrm{H} \mathrm{F} 2$ and $\mathrm{C} 3 \mathrm{HB} 6 \mathrm{~F} 2$ hybrids $(P>0 \cdot 1)$.
Comparison of body weight variation between the two crosses

A similar discrepancy was also reflected in concurrent body weight. Although $\mathrm{C} 3 \mathrm{H}$ female mice weighed less than their $\mathrm{B} 6$ counterparts at $\mathrm{VO}$ (as $\mathrm{VO}$ is triggered much earlier in $\mathrm{C} 3 \mathrm{H}$ mice than in $\mathrm{B} 6$ mice), $\mathrm{C} 3 \mathrm{H}$ and $\mathrm{C} 3 \mathrm{HB} 6 \mathrm{~F} 1$ female mice weighed more than $\mathrm{B} 6$ and $\mathrm{B} 6 \mathrm{C} 3 \mathrm{H} \mathrm{F} 1$ mice at the same age $\left(P=4 \cdot 8 \times 10^{-7}\right.$ and $0 \cdot 018$ respectively), while direct and reciprocal F2 hybrids had similar body weight at VO $(P=0 \cdot 614$; Table 1$)$.

The body weight of $\mathrm{C} 3 \mathrm{H}$ and $\mathrm{C} 3 \mathrm{HB} 6 \mathrm{~F} 1$ male mice at BPS was much greater than that of $\mathrm{B} 6$ and $\mathrm{B} 6 \mathrm{C} 3 \mathrm{H} \mathrm{F} 1$ mice $\left(P=2 \cdot 2 \times 10^{-4}\right.$ and $9 \cdot 7 \times 10^{-8}$ respectively), while the difference in body weight at BPS vanished in F2 hybrids $(P=0 \cdot 313$; Table 2).

$\mathrm{C} 3 \mathrm{H}$ female mice were heavier than their $\mathrm{B} 6$ counterparts at birth $(P<0 \cdot 005)$. Female F1 hybrids with a $\mathrm{C} 3 \mathrm{H}$ maternal parent were heavier at birth than those with B6 mothers $(P<0 \cdot 001)$, although both had the same genotype and they had the same birth weight as their mothers. Similarly, the male hybrid progeny from $\mathrm{C} 3 \mathrm{H}$ females were heavier than those from B6 females.

\section{Fostering experiment}

The differences in the time of puberty onset and the concurrent body weight between the reciprocal crosses of F1 hybrids could be caused by many factors apart from genetic background as all the F1 hybrids had the same genotype. In order to exclude the effects of post birth nutrition and maternal behavior/mothering on this trait, a fostering experiment on another group of F1 hybrids was carried out. The results of the fostering experiment were described by growth curves of the parental strains and the F1 hybrid progeny. The growth curves indicated that $\mathrm{C} 3 \mathrm{H}$ female mice grew faster than their B6 counterparts, and their F1 hybrid female progeny had a similar difference in growth rate (Fig. 3). $\mathrm{C} 3 \mathrm{H}$ male mice grew at a similar rate as $\mathrm{B} 6$ male mice, while their hybrid male progeny had a significantly different growth rate (Fig. 4). The puberty onset status of these animals was similar to that of their counterparts fostered by their own mothers (data not shown) and the difference between the two reciprocal crosses of F1 hybrids continued.

\section{Heterosis}

Heterosis was defined as the difference between the traits of interest in the hybrid progeny compared with those of their inbred parents. In this study, heterosis was evaluated by fecundity in female mice (shown by litter size) and puberty advance in male mice.

The assumption of heterosis of fecundity was assessed by analysis of variance (ANOVA), with the maternal gene background as the independent variable and litter size as the dependent variable. The discrepancy was highly significant between mothers with an F1 heterogenic background and 
Table 1 Comparison of body weight at birth and at vaginal opening (VO) between parent, direct and reciprocal crosses in F1 and F2 hybrids of female mice

\begin{tabular}{|c|c|c|c|c|}
\hline & Number & $\begin{array}{l}\text { Weight at birth } \\
\text { (g; mean } \pm \text { s.D.) }\end{array}$ & $\begin{array}{l}\text { Weight at VO } \\
(\mathrm{g} ; \text { mean } \pm \text { s.D. })\end{array}$ & $\begin{array}{l}\text { Probability values } \\
\text { Mann-Whitney }\end{array}$ \\
\hline \multicolumn{5}{|c|}{ Gene background } \\
\hline B6 & 37 & $1 \cdot 40 \pm 0 \cdot 15^{*}$ & $13 \cdot 48 \pm 1 \cdot 57$ & \multirow{2}{*}{$4 \cdot 8 \times 10^{-7}$} \\
\hline $\mathrm{C} 3 \mathrm{H}$ & 36 & $1 \cdot 66 \pm 0.23^{+}$ & $11 \cdot 29 \pm 1 \cdot 48$ & \\
\hline \multicolumn{5}{|l|}{ F1 hybrids } \\
\hline $\mathrm{B} 6 \times \mathrm{C} 3 \mathrm{H}$ & 56 & $1 \cdot 30 \pm 0 \cdot 16^{\neq}$ & $13 \cdot 36 \pm 1 \cdot 59$ & $0 \cdot 018$ \\
\hline $\mathrm{B} 6 \times \mathrm{C} 3 \mathrm{H}$ & 104 & & $12 \cdot 80 \pm 1 \cdot 96$ & \multirow[t]{2}{*}{$0 \cdot 614$} \\
\hline $\mathrm{C} 3 \mathrm{H} \times \mathrm{B} 6$ & 147 & & $13 \cdot 10 \pm 2 \cdot 14$ & \\
\hline
\end{tabular}

Superscripts following means indicate Tukey groupings for significantly different means.

mothers with a B6 $\left(F_{1,107}=7 \cdot 314, P=8 \cdot 0 \times 10^{-3}\right)$ or $\mathrm{C} 3 \mathrm{H}$ $\left(F_{1,101}=30 \cdot 805, \quad P=2 \cdot 3 \times 10^{-7}\right)$ homogenic background (Fig. 5).

On the other hand, BPS of male mice occurred earlier in F1 and F2 hybrids than in the parental strains. As shown in Fig. 6, timing of BPS in F1 hybrids $(28 \cdot 7 \pm 1 \cdot 3$ days in B6C3H F1 and $27 \cdot 2 \pm 1 \cdot 2$ days in C3HB6 F1) is earlier than the minimum threshold in the parental strains $(29 \cdot 6 \pm 1 \cdot 5$ days in $\mathrm{B} 6$ and $29 \cdot 2 \pm 1 \cdot 8$ days in $\mathrm{C} 3 \mathrm{H})$. BPS was triggered significantly earlier in all F2 progeny compared with parental strains $(P<0 \cdot 001)$.

\section{Heritability}

Heritability was evaluated only in female mice and was calculated using the following formula:

$h^{2}=\frac{V_{\mathrm{G}}}{V_{\mathrm{T}}}=\frac{V_{\mathrm{F} 2}-V_{\mathrm{E}}}{V_{\mathrm{F} 2}}=\frac{\left[V_{F 2}-1 / 3\left(V_{\mathrm{P} 1}+V_{\mathrm{P} 2}+V_{\mathrm{F} 1}\right)\right]}{V_{\mathrm{F} 2}}$

where $V_{\mathrm{G}}$ is the variance for genetic effect in the F2 population, $V_{\mathrm{T}}$ is the total variance in the $\mathrm{F} 2$ population, $V_{\mathrm{E}}$ is the total variance for the environmental effect in the F2 population, and $V_{\mathrm{F} 2}, V_{\mathrm{P} 1}, V_{\mathrm{P} 2}$ and $V_{\mathrm{F} 1}$ are the computed variances for the F2, P1, P2 and F1 populations respectively (Table 3).

For $\mathrm{B} 6 \mathrm{C} 3 \mathrm{H} \mathrm{F} 2$, the computed heritability of timing of $\mathrm{VO}$ is

$$
\begin{aligned}
h^{2} & =\frac{\left[V_{\mathrm{F} 2}-1 / 3\left(V_{\mathrm{P} 1}+V_{\mathrm{P} 2}+V_{\mathrm{F} 1}\right)\right]}{V_{\mathrm{F} 2}} \\
& =\frac{[11 \cdot 56-1 / 3(1 \cdot 44+3 \cdot 24+6 \cdot 25)]}{11 \cdot 56}=0.6851
\end{aligned}
$$

For C3HB6 F2, the computed heritability of timing of $\mathrm{VO}$ is

$$
\begin{aligned}
h^{2} & =\frac{\left[V_{\mathrm{F} 2}-1 / 3\left(V_{\mathrm{P} 1}+V_{\mathrm{P} 2}+V_{\mathrm{F} 1}\right)\right]}{V_{\mathrm{F} 2}} \\
& =\frac{[8.41-1 / 3(1.44+3.24+4.41)]}{8.41}=0.6397
\end{aligned}
$$

The heritability of timing of puberty is $68 \cdot 51 \%$ and $63 \cdot 97 \%$

\begin{tabular}{|c|c|c|c|}
\hline Number & $\begin{array}{l}\text { Weight at birth } \\
\text { (g; mean } \pm \text { S.D.) }\end{array}$ & $\begin{array}{l}\text { Weight at BPS } \\
(\mathrm{g} ; \text { mean } \pm \text { S.D. })\end{array}$ & $\begin{array}{l}\text { Probability values } \\
\text { Mann-Whitney }\end{array}$ \\
\hline $\begin{array}{l}27 \\
28\end{array}$ & $\begin{array}{l}1 \cdot 43 \pm 0 \cdot 12^{*} \\
1 \cdot 53 \pm 0 \cdot 15^{\dagger}\end{array}$ & $\begin{array}{l}17 \cdot 54 \pm 0 \cdot 19 \\
18 \cdot 62 \pm 1 \cdot 06\end{array}$ & $2 \cdot 2 \times 10^{-4}$ \\
\hline $\begin{array}{l}76 \\
30\end{array}$ & $\begin{array}{l}1 \cdot 27 \pm 0 \cdot 19^{\ddagger} \\
2 \cdot 05 \pm 0 \cdot 28^{\S}\end{array}$ & $\begin{array}{l}17 \cdot 07 \pm 0 \cdot 73 \\
18 \cdot 94 \pm 1 \cdot 86\end{array}$ & $9 \cdot 7 \times 10^{-8}$ \\
\hline $\begin{array}{r}98 \\
149\end{array}$ & & $\begin{array}{l}18 \cdot 45 \pm 1 \cdot 31 \\
18 \cdot 60 \pm 1 \cdot 52\end{array}$ & $0 \cdot 313$ \\
\hline
\end{tabular}
in direct and reciprocal crosses respectively.

Table 2 Comparison of body weight at birth and at balano preputial separation (BPS) between parent, direct and reciprocal crosses in F1 and F2 hybrids of male mice

Superscripts following means indicate Tukey groupings for significantly different means. 


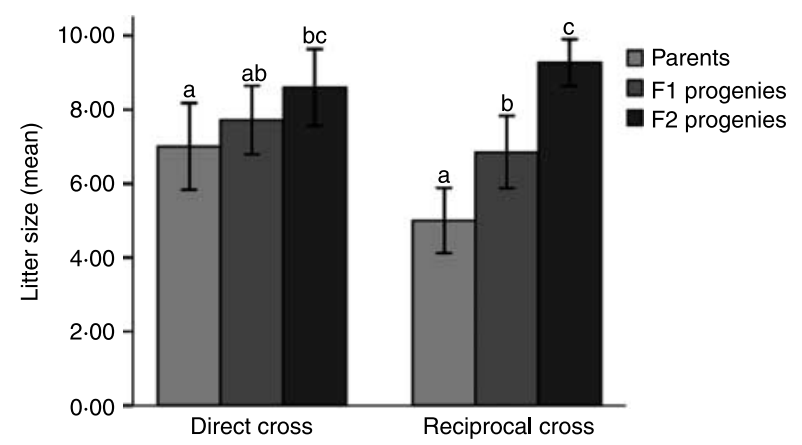

Figure 3 Growth curves of two inbred strains of female mice and the direct and reciprocal $\mathrm{FI}$ crosses. $\mathrm{N}$ indicates the number of pups included.

\section{Discussion}

The onset of puberty, which involves the activation of hypothalamic function and maturation of the pituitarygonadal axis, is a complex trait affected by both genetic and environmental factors. The calculated heritability from our experiments on inbred mice indicated that up to $63-70 \%$ of the variance in the pubertal timing of female mice is genetically determined, consistent with previous results from human population groups.

For a quantitative trait which is determined only by the nuclear genome, the phenotype distribution of hybrid progeny from two inbred strains is as follows: there is no distributional difference between direct and reciprocal crosses of F1 hybrids as their genotype is the same; the distribution of F2 hybrids is between those of the parental strains, with the mean varying according to the hereditary model. Our experiments revealed, for the first time, that there was significant discrepancy in the timing of puberty onset and the concurrent body weight increase between direct and reciprocal crosses in F1 but not in F2 hybrid mice of both genders. The discrepancy between F1 progeny with the same genotype could be ascribed to maternal effects as well as to mitochondrial haplotype if such a discrepancy continued in

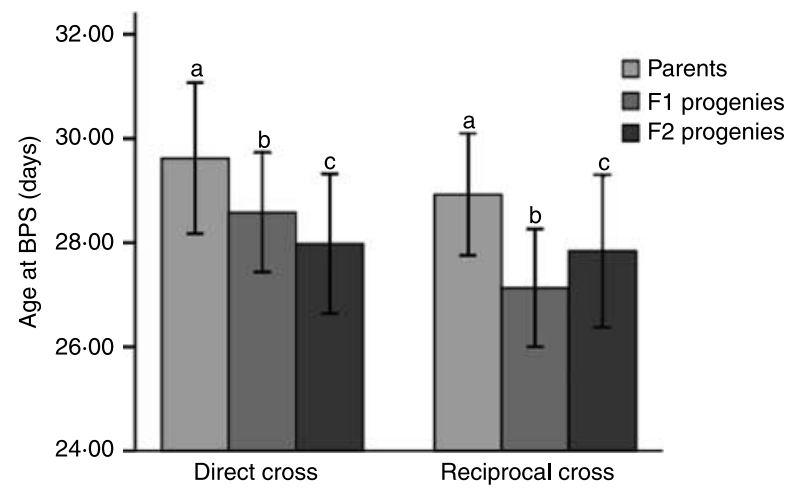

Figure 4 Growth curves of two inbred strains of male mice and the direct and reciprocal $\mathrm{Fl}$ crosses. $\mathrm{N}$ indicates the number of pups included.

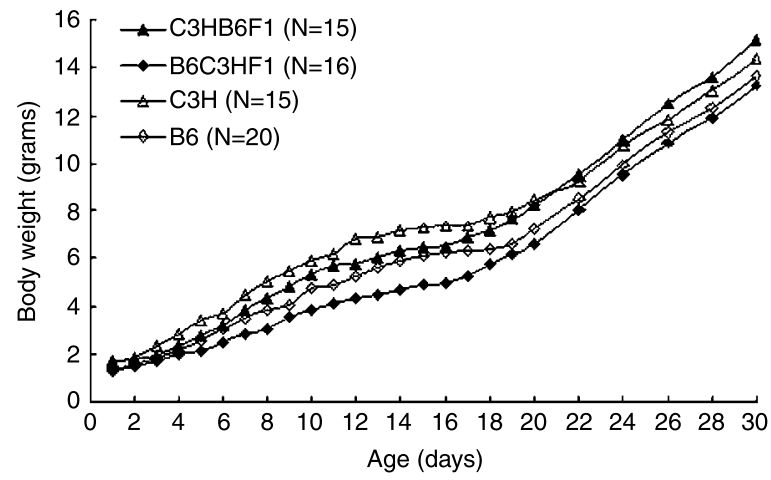

Figure 5 Comparison of litter size among three generations of female mice in direct and reciprocal crosses. Direct cross: $\mathrm{B} 6 \times$ $\mathrm{C} 3 \mathrm{H}$, reciprocal cross: $\mathrm{C} 3 \mathrm{H} \times \mathrm{B} 6$. Letters at the top of the columns indicate Tukey groupings for significantly different means.

F2 hybrids, because mitochondria of direct and reciprocal F2 progeny were derived from different progenitors. Although genotype differed in the F2 hybrids, a large number of individuals would still be able to reflect an effect of the mitochondrial haplotype if such an effect existed. But in fact, VO and BPS occurred at the same age in either cross of F2 progeny, which meant that different mitochondrial haplotypes had not affected this trait. Therefore, it is reasonable to suppose that the maternal nuclear genetic background may account for the observed discrepancy between direct and reciprocal F1 progeny. In order to avoid the influence of post birth nutrition and maternal behavior on the timing of pubertal onset in offspring, fostering experiments were carried out on a complementary group of F1 hybrids. The results showed that even when fostered by mothers with the same genetic background, F1 hybrids of a contrasting cross grew at a different rate and pubertal onset occurred at a different age, even though they had the same genotype; this suggests that such a difference was brought about prenatally rather than postnatally.

The maternal nuclear genome may impact on the timing of puberty of offspring in both direct and indirect ways; the former may be through genes associated with physiological status during pregnancy that influence the development of the fetus in the uterus. The latter may be through imprinting genes which can be differentially expressed when inherited from either the maternal or the paternal parent to affect growth and development of offspring.

Research in many organisms has shown that maternal hormones (Eising et al. 2001), and maternal mRNA in eggs (Nagler 2000) can influence embryonic development. Androgens, corticosteroids and thyroid hormones are among the maternally derived hormones with significant roles during embryonic development in vertebrates. Previous studies showed that ingredient variations in the maternal diet during pregnancy and lactation could affect the pubertal status of female progeny (Cooper et al. 1996, Lumey \& Stein 1997, Magnusson et al. 1999, Adair 2001, Leonhardt et al. 2003, 


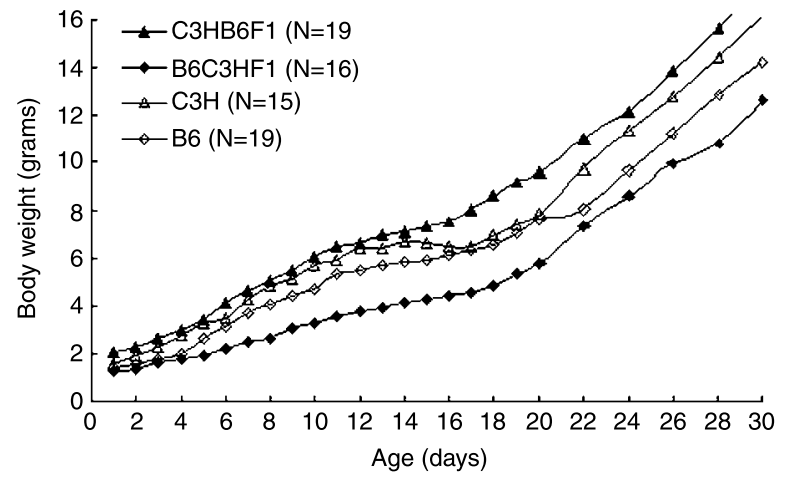

Figure 6 Comparison of age at BPS among three generations of male mice in direct and reciprocal crosses. Direct cross: $\mathrm{B} 6 \times \mathrm{C} 3 \mathrm{H}$, reciprocal cross: $\mathrm{C} 3 \mathrm{H} \times \mathrm{B} 6$. Letters at the top of the columns indicate Tukey groupings for significantly different means.

Guzman et al. 2006). Experiments on rats showed that maternal exposure to a high level of serum estradiol during pregnancy advanced $\mathrm{VO}$ in female offspring (Hilakivi-Clarke et al. 1997). In essence, Wang et al. (2006) conducted a candidate gene association study on birth weight and fetal growth restriction in two independent samples and provided consistent evidence that SNP rs2297660 in the maternal LRP8 gene was associated with fetal growth. These experiments suggested that maternal gene polymorphisms might result in trait variations related to fetus development perinatally. Identification of maternal genes associated with intra-uterine physiological status may help to unravel the maternal genetic specification of and the physiological basis for the timing of puberty in progeny.

A number of loci related to growth and development have been shown to be imprinted (including insulin-like growth factor (IGF)-II, IGF-II receptor, Insulin 1 (Ins1), and Ins2) and cause the imprinting effect associated with identified QTL (Van Laere et al. 2003). Overweight children, especially girls, tend to mature earlier than lean children, which implies that the degree of body fatness may trigger the neuroendocrine events that lead to the onset of puberty (Shalitin \& Phillip 2003), while the parent-of-origin effects, perhaps including genomic imprinting, play a role in human obesity (Dong et al. 2005). Such correlations may suggest some association between imprinting genes and pubertal development. Further studies on the imprinting pattern of $\mathrm{GnRH}$ (gonadotropin releasing hormone) neuron of different developmental stages may help to clarify the mechanism of puberty about the mechanism of this trait. Correlation between the ages at which a mother and her son or daughter attained various pubertal milestones provide extra evidence of maternal genetic regulation of the timing of puberty (Garn \& Bailey 1978).

The parental strain of mice $(\mathrm{C} 3 \mathrm{H}$ and $\mathrm{B} 6)$ with a homogeneous allele at each genetic locus may be physiologically weaker than their hybrid progeny, as they have lower fertility and viability, defined as heterosis. Heterosis in the
Table 3 Standard deviations and computed variances of timing of vaginal opening $(\mathrm{VO})$ in female mice

\begin{tabular}{|c|c|c|c|}
\hline & \multicolumn{2}{|c|}{ Timing of VO (day) } & \multirow{2}{*}{ Variance $\left(\right.$ S.D. $\left.{ }^{2}\right)$} \\
\hline & Average & S.D. & \\
\hline \multicolumn{4}{|c|}{ Gene background } \\
\hline \multicolumn{4}{|c|}{ Parental strain } \\
\hline B6 & $27 \cdot 6$ & $1 \cdot 2$ & $1 \cdot 44$ \\
\hline $\mathrm{C} 3 \mathrm{H}$ & $22 \cdot 6$ & $1 \cdot 8$ & $3 \cdot 24$ \\
\hline \multicolumn{4}{|l|}{ F1 hybrids } \\
\hline $\mathrm{B} 6 \times \mathrm{C} 3 \mathrm{H}$ & $27 \cdot 0$ & $2 \cdot 5$ & $6 \cdot 25$ \\
\hline $\mathrm{C} 3 \mathrm{H} \times \mathrm{B} 6$ & $25 \cdot 6$ & $2 \cdot 1$ & $4 \cdot 41$ \\
\hline \multicolumn{4}{|l|}{ F2 hybrids } \\
\hline $\mathrm{B} 6 \times \mathrm{C} 3 \mathrm{H}$ & $24 \cdot 0$ & $3 \cdot 4$ & $11 \cdot 56$ \\
\hline $\mathrm{C} 3 \mathrm{H} \times \mathrm{B} 6$ & $23 \cdot 9$ & $2 \cdot 9$ & $8 \cdot 41$ \\
\hline
\end{tabular}

fecundity of female mice (evaluated by litter size) could be supported by the larger litter size of hybrid progeny compared with that of their progenitor. F1 hybrid female mice, which were genetically heterogeneous at each locus, could procreate more progeny than their maternal progenitor. Heterosis may improve the mother's intra-uterine physiological status, which may be an important factor for reproductive function and pubertal development. Furthermore, inbred female mice give birth to more hybrid than inbred progeny (litter size: $7 \cdot 5$ vs $7 \cdot 0$ for B6 and $6 \cdot 8$ vs $5 \cdot 0$ for $\mathrm{C} 3 \mathrm{H}$; Fig. 5 ), which could be the result of stronger vitality of the hybrid embryo than that of the inbred one in utero.

Heterosis can also be exhibited in male mice by earlier timing of BPS in F1 and F2 progeny compared with that of their paternal progenitor. In our experiment, a significantly different BPS onset time was observed between direct and reciprocal F1 hybrid males, but not between the two parental strains. Hybrid progeny from $\mathrm{C} 3 \mathrm{H}$ mothers grew faster than their inbred counterparts, and they triggered earlier BPS than the latter. Maternal effects were reflected significantly in F1 hybrids, but concealed in parental strains due to their physiological weakness, as male hybrid progeny from $\mathrm{C} 3 \mathrm{H}$ mothers triggered BPS earlier than those from B6 females while the inbred paternal mice had the same BPS onset time. The physiological weakness of the inbred strains could be manifested as later BPS timing than their hybrid progeny. The discrepancy between direct and reciprocal F1 hybrids may be interpreted by their improved physiological status, so as to show the maternal effects on this trait.

From our data it would seem that puberty onset time was associated with growth velocity in mice as, in general, the faster the mice grew, the earlier they attained the onset of puberty. The relationship was more significant in the male than in the female. However, vaginal opening in female $\mathrm{C} 3 \mathrm{H}$ mice was triggered much earlier than in their B6 counterparts but $\mathrm{C} 3 \mathrm{H}$ mice were much lighter than the latter (Table 1), suggesting that the onset of puberty was not solely dependent on body weight. 
Most of the genes and pathways are shared between mice and humans and a growing number of examples demonstrate that the investigation of variation among inbred mouse strains can be applied to analysis of the genetic model of human traits and diseases (Bedell et al. 1997, Darvasi 1998, Jansen 2003). Our studies reveal that the maternal nuclear genome, probably through imprinting genes and the genes associated with intra-uterine physiological status, plays a role in determining the timing of puberty in mice. It is reasonable to suspect that such an effect of the maternal nuclear genome also exists in humans. In clinical practice, there are many patients suffering from puberty disorders, and genetic analysis is regarded as a particularly suitable way to identify allelic variants of candidate genes that are associated with variations in the timing of puberty. Our results indicate that integration of the effects of the maternal nuclear genome on the timing of puberty may help to unravel the genetic specification of and physiologic basis for this trait.

\section{Funding}

This work was supported by a grant from the National Nature Science Foundation of China (grant no. 30300198) to Junhua Xiao. The authors declare that there is no conflict of interest that would prejudice the impartiality of this scientific work.

\section{References}

Adair LS 2001 Size at birth predicts age at menarche. Pediatrics 107 e59. Bedell MA, Largaespada DA, Jenkins NA \& Copeland NG 1997 Mouse models of human disease. Part II: recent progress and future directions. Genes and Development 11 11-43.

Cooper C, Kuh D, Egger P, Wadsworth M \& Barker D 1996 Childhood growth and age at menarche. British Journal of Obstetrics and Gynaecology 103 814-817.

Darvasi A 1998 Experimental strategies for the genetic dissection of complex traits in animal models. Nature Genetics 18 19-24.

Dong C, Li WD, Geller F, Lei L, Li D, Gorlova OY, Hebebrand J, Amos CI, Nicholl RD \& Price RA 2005 Possible genomic imprinting of three human obesity-related genetic loci. American Journal of Human Genetics 76 427-437.

Eising CM, Eikenaar C, Schwabl H \& Groothuis TGG 2001 Maternal androgens in black-headed gull (Larus ridibundus) eggs: consequences for chick development. Proceedings of the Royal Society of London. Series B. Biological Sciences 268 839-846.

Francis JP 2005 The neuroendocrine timing of puberty. Reproduction 129 675-683.

Garn SM \& Bailey SM 1978 Genetics and maturational processes. In Human Growth 1: Principles and Prenatal Growth, pp 307-330. Eds F Falkner \& JM Tanner. New York: Plenum Press.

Grosso S, Berardi R, Pucci L \& Balestri P 1999 Precocious puberty with trisomy X syndrome. Obstetrics and Gynecology 94861.

Guzman C, Cabrera R, Cárdenas M, Larrea F, Nathanielsz PW \& Zambrano E 2006 Protein restriction during fetal and neonatal development in the rat alters reproductive function and accelerates reproductive ageing in female progeny. Journal of Physiology $\mathbf{5 7 2} 97-108$.
Hilakivi-Clarke L, Clarke R, Onojafe I, Raygada M, Cho E \& Lippman M 1997 A maternal diet high in n-6 polyunsaturated fats alters mammary gland development, puberty onset, and breast cancer risk among female rat offspring. PNAS 94 9372-9377.

Ibanez L, Jimenez R \& Zegher F 2006 Early puberty-menarche after precocious pubarche: relation to prenatal growth. Pediatrics 117 117-121.

Jansen RC 2003 Studying complex biological systems using multifactorial perturbation. Nature Reviews. Genetics 4 145-151.

Jarvela IE, Salo MK, Santavuori P \& Salonen RK 1993 46, XX/69, XXX diploid-triploid mixoploidy with hypothyroidism and precocious puberty. Journal of Medical Genetics 30 966-967.

Kadlubar FF, Berkowitz GS \& Delongehanp RR 2001 The putative highactivity variant, $C Y P 3 A 4 \star 1 \mathrm{~B}$, predicts the onset of puberty in young girls. Cancer Research 42 408-419.

Kadlubar FF, Berkowitz GS, Delongchamp RR, Charles W, Green LB \& George T 2003 The CYP3A4^1B variant is related to the onset of puberty, a known risk factor for the development of breast cancer. Cancer Epidemiology, Biomarkers and Prevention 12 327-331.

Krewson TD, Supelak PJ, Hill AE, Singer JB, Lander ES, Nadeau JH \& Palmert MR 2003 Chromosomes 6 and 13 harbor genes that regulate pubertal timing in mouse chromosome substitution strains. Endocrinology 145 4447-4451.

Van Laere AS, Nguyen M, Braunschweig M, Nezer C, Collette C, Moreau L, Archibald AL, Haley CS, Buys N \& Tally M 2003 A regulatory mutation in IGF2 causes a major QTL effect on muscle growth in the pig. Nature $\mathbf{4 2 5}$ 832-836.

Leonhardt M, Lesage J, Croix D, Dutriez-Casteloot I, Beauvillain JC \& Dupouy JP 2003 Effects of perinatal maternal food restriction on pituitarygonadal axis and plasma leptin level in rat pup at birth and weaning and on timing of puberty. Biology of Reproduction 68 390-400.

Loesch DZ, Hopper JL, Rogucka E \& Huggins RM 1995 Timing and genetic rapport between growth in skeletal maturity and height around puberty: Commentary on 2367 similarities and differences between girls and boys. American Journal of Human Genetics 56 753-759.

Lumey LH \& Stein AD 1997 In utero exposure to famine and subsequent fertility: the Dutch Famine Birth Cohort Study. American Journal of Public Health 87 1962-1966.

Magnusson CM, Persson IR, Baron JA, Ekbom A, Bergstrom R \& Adami HO 1999 The role of reproductive factors and use of oral contraceptives in the etiology of breast cancer in women aged 50 to 74 years. International Journal of Cancer 80 231-236.

Meyer JM, Eaves LJ, Heath AC \& Martin NG 1991 Estimating genetic influences on the age-at-menarche: a survival analysis approach. American Journal of Medical Genetics 39 148-154.

Nagler JJ 2000 In vivo treatment with cycloheximide or actinomycin D inhibits early embryonic development in rainbow trout (Oncorhynchus mykiss). Fish Physiology and Biochemistry 22 61-66.

Nelson JF, Felicio KK \& Johnson TE 1990 Genetic influences on the timing of puberty in mice. Biology of Reproduction 42 649-655.

Palmert MR \& Boepple PA 2001 Variation in the timing of puberty: clinical spectrum and genetic investigation. Journal of Clinical Endocrinology and Metabolism 86 2364-2368.

Palmert MR \& Hischhorn JN 2003 Genetic approaches to stature, pubertal timing, and other complex traits. Molecular Genetics and Metabolism 80 1-10.

Persson I, Ahlsson F \& Ewald U 1999 Influence of perinatal factors on the onset of puberty in boys and girls. Americam Journal of Epidemiology 150 $747-755$.

Rockhill B, Moorman PG \& Newman B 1998 Age at menarche, time to regular cycling, and breast cancer (North Carolina, United States). Cancer Causes Control 9 447-453.

Roux N, Genin E, Carel JC, Matsuda F, Chaussain JL \& Milgrom E 2003 Hypogonadotropic hypogonadism due to loss of function of the KiSS1derived peptide receptor GPR54. PNAS 100 10972-10976.

Seminara SB, Messager S, Chatzidaki EE, Thresher RR, Acierno JS, Shagoury JK, Bo-Abbas Y, Kuohung W, Schwinof KM \& Hendrick AG 2003 The GPR 54 gene as a regulator of puberty. New England Journal of Medicine 349 1614-1627. 
Shalitin S \& Phillip M 2003 Role of obesity and leptin in the pubertal process and pubertal growth. Journal of Obesity 27 869-874.

Sisk CL \& Foster DL 2004 The neural basis of puberty and adolescence. Nature Neuroscience 7 1040-1047.

Talaban R, Sellick GS, Spendlove HE, Howell R, King C, Reckless J, Newbury-Ecob R \& Houlston RS 2005 Inherited pericentric inversion (X; p11.4q11.2) associated with delayed puberty and obesity in two brothers. Cytogenetic and Genome Research 109 480-484.

Vries L, Kauschansky A, Shohat M \& Phillip M 2004 Familial central precocious puberty suggests autosomal dominant inheritance. Journal of Clinical Endocrinology and Metabolism 89 1794-1800.

Wang L, Wang X, Laird N, Zuckerman B, Stubblefield P \& Xu X 2006 Polymorphism in maternal LRP8 gene is associated with fetal growth. American Journal of Human Genetics 78 770-777.
Wattigney WA, Srinivasan SR, Cenw W, Greenlund KJ \& Berenson GS 1999 Secular trend of earlier onset of menarche with increasing obesity in black and white girls: the Bogalusa Heart Study. Ethnicity and Disease 9 181-189.

Wyatt G, Durvasula RS, Guthrie D, LeFranc E \& Forge N 1999 Correlates of first intercourse among women in Jamaica. Archives of Sexual Behavior $\mathbf{2 8}$ $139-157$.

Received in final form 2 March 2007

Accepted 6 March 2007

Made available online as an Accepted Preprint 8 March 2007 